\title{
Effect of prone positioning on oxygenation and static respiratory system compliance in COVID-19 ARDS versus non-COVID ARDS
}

\section{Jimyung Park}

Seoul National University Hospital

Hong Yeul Lee

Seoul National University Hospital

Jinwoo Lee

Seoul National University Hospital

Sang-Min Lee ( $\nabla$ sangmin2@snu.ac.kr)

Seoul National University College of Medicine https://orcid.org/0000-0002-1388-9318

\section{Research}

Keywords: COVID-19, Acute respiratory distress syndrome, Prone position, Oxygenation, Respiratory system compliance

Posted Date: May 5th, 2021

DOl: https://doi.org/10.21203/rs.3.rs-441349/v1

License: (9) This work is licensed under a Creative Commons Attribution 4.0 International License. Read Full License

Version of Record: A version of this preprint was published at Respiratory Research on August 6th, 2021. See the published version at https://doi.org/10.1186/s12931-021-01819-4. 


\section{Abstract}

Background: Prone positioning is recommended for patients with moderate-to-severe acute respiratory distress syndrome (ARDS) receiving mechanical ventilation. While the debate continues as to whether COVID-19 ARDS is clinically different from non-COVID ARDS, there is little data on whether the physiological effects of prone positioning differ between the two conditions. We aimed to compare the physiological effect of prone positioning between patients with COVID-19 ARDS and those with nonCOVID ARDS.

Methods: We retrospectively compared 23 patients with COVID-19 ARDS and 145 patients with nonCOVID ARDS treated using prone positioning while on mechanical ventilation. Changes in $\mathrm{PaO}_{2} / \mathrm{FiO}_{2}$ ratio and static respiratory system compliance (Crs) after the first session of prone positioning were compared between the two groups: first, using all patients with non-COVID ARDS, and second, using subgroups of patients with non-COVID ARDS matched 1:1 with patients with COVID-19 ARDS for baseline $\mathrm{PaO}_{2} / \mathrm{FiO}_{2}$ ratio and static $\mathrm{Crs}$. We also evaluated whether the response to the first prone positioning session was associated with the clinical outcome.

Results: When compared with the entire group of patients with non-COVID ARDS, patients with COVID-19 ARDS showed more pronounced improvement in the $\mathrm{PaO}_{2} / \mathrm{FiO}_{2}$ ratio (adjusted difference $39.3[95 \% \mathrm{Cl}$ 5.2-73.5] mmHg) and static Crs (adjusted difference 3.4 [95\% $\mathrm{Cl} 1.1-5.6] \mathrm{mL} / \mathrm{cmH}_{2} \mathrm{O}$ ). However, these between-group differences were not significant when the matched samples (either $\mathrm{PaO}_{2} / \mathrm{FiO}_{2}$-matched or compliance-matched) were analyzed. The improvements in $\mathrm{PaO}_{2} / \mathrm{FiO}_{2}$ ratio (subdistribution hazard ratio $1.19,95 \% \mathrm{Cl} 1.08-1.30$ ) and static Crs (subdistribution hazard ratio 1.57, 95\% Cl 1.29-1.91) after the first prone positioning session were associated with successful discontinuation of mechanical ventilation in patients with COVID-19 ARDS.

Conclusions: In patients with COVID-19 ARDS, prone positioning was as effective in improving respiratory physiology as in patients with non-COVID ARDS. Thus, it should be actively considered as a therapeutic option. The physiological response to the first session of prone positioning was predictive of the clinical outcome of patients with COVID-19 ARDS.

\section{Background}

After its first outbreak in Wuhan, China in December 2019, coronavirus disease 2019 (COVID-19) spread rapidly around the world and continues to be a global threat (1). Although most patients with COVID-19 have mild manifestations, the condition deteriorates in approximately $10 \%-20 \%$ of patients, requiring admission to an intensive care unit and invasive mechanical ventilation for acute respiratory distress syndrome (ARDS) (2-4). Whether ARDS due to COVID-19 (COVID-19 ARDS) is clinically distinct from ARDS due to other causes (non-COVID ARDS) has been a controversial issue $(5,6)$. 
Prone positioning is currently implemented for patients with moderate-to-severe ARDS with the potential to reduce mortality (7). The beneficial effect of prone positioning on oxygenation has been known for decades, but whether the improvement in oxygenation is directly associated with patients' survival gain has been questionable (8). We have recently shown that the extent of improvement in the ratio of partial pressure of arterial oxygen $\left(\mathrm{PaO}_{2}\right)$ to the fraction of inspired oxygen $\left(\mathrm{FiO}_{2}\right)$ after prone positioning could be a predictor of survival of patients with ARDS (9).

In this study, we aimed to investigate whether physiological responses to prone positioning differ between patients with COVID-19 ARDS and those with non-COVID ARDS, focusing not only on oxygenation, but also on static respiratory system compliance (Crs), considering recent studies that reported a prognostic value of static Crs for COVID-19 ARDS $(10,11)$. We also evaluated whether the response to the first session of prone positioning was associated with patients' clinical outcome.

\section{Methods}

\section{Patients with COVID-19 ARDS}

This study was a retrospective cohort study using the patients' medical records conducted at the Seoul National University Hospital, a tertiary referral hospital in South Korea, which has served as a nationally designated hospital for patients with severe and critical COVID-19. This study was approved by the institutional review board of the Seoul National University Hospital (IRB No. 2012-036-1179). We reviewed the records of all patients older than 18 years who were admitted to our center between January and December 2020 after being diagnosed as having COVID-19 using reverse transcription-polymerase chain reaction assay. Among such patients, those for whom mechanical ventilation was initiated and prone positioning was implemented were included in this study.

\section{Treatment and prone positioning}

Patients with COVID-19 ARDS were treated based on the most updated evidence at the time of their hospitalization $(12,13)$. In patients with worsening respiratory failure, we usually used a high flow nasal cannula at first, but mechanical ventilation with endotracheal intubation was initiated in refractory cases (14). If $\mathrm{PaO}_{2} / \mathrm{FiO}_{2}$ ratio after initiation of mechanical ventilation was less than $200 \mathrm{mmHg}$, we actively considered prone positioning with neuromuscular blockade $(7,15)$. Prone position was maintained for at least 16 hours per day (7). Discontinuation of prone positioning was considered if reduction in ventilator assistance was possible allowing for spontaneous or assisted ventilation.

\section{Comparison with non-COVID ARDS}

We reviewed every patient with non-COVID ARDS treated using prone positioning while on mechanical ventilation since January 2014 until December 2020, and the cohort of these patients was used for a comparison between COVID-19 ARDS and non-COVID ARDS. Some of these patients were included in our previous study (9). First, we used the entire group of patients with non-COVID ARDS while 
adjusting for the between-group differences. Second, for a more accurate comparison, patients with COVID-19 ARDS were matched with subgroup populations among the non-COVID ARDS group: one matched 1:1 for $\mathrm{PaO}_{2} / \mathrm{FiO}_{2}$ ratio and one matched 1:1 for static Crs.

\section{Study outcome and data collection}

The primary outcome of this study was the extent of changes in $\mathrm{PaO}_{2} / \mathrm{FiO}_{2}$ ratio and static $\mathrm{Crs}$ after the first prone positioning session. In each patient, the changes in $\mathrm{PaO}_{2} / \mathrm{FiO}_{2}$ ratio and static $\mathrm{Crs}$ were tracked during the first prone positioning session. Using the results of arterial blood gas analysis and the ventilator setting at the time of blood sampling, $\mathrm{PaO}_{2} / \mathrm{FiO}_{2}$ ratio and static Crs were evaluated at four timepoints for each patient: baseline (before initiation of prone positioning), P1 (approximately 10 hours after initiation of prone positioning), P2 (approximately 16 hours after initiation of prone positioning, which is the last timepoint before cessation of prone positioning), and S1 (approximately 2 hours after changing to supine position). For the main outcome of this study, each patient's response to the first session of prone positioning was calculated as the difference in $\mathrm{PaO}_{2} / \mathrm{FiO}_{2}$ ratio and static $\mathrm{Crs}$ between the baseline and P2 timepoints.

\section{Statistical analysis}

We assessed the differences between patients with COVID-19 ARDS and those with non-COVID ARDS and $P$ values of $<0.05$ for two-tailed tests were considered statistically significant. First, all patients with non-COVID ARDS were compared with patients with COVID-19 ARDS. Then, two subgroup populations of patients with non-COVID ARDS were used for 1:1 matched comparison with patients with COVID-19 ARDS ( $\mathrm{PaO}_{2} / \mathrm{FiO}_{2}$-matched subgroup and compliance-matched subgroup). The matching was performed using an optimal algorithm without replacement (16).

The extent of changes in $\mathrm{PaO}_{2} / \mathrm{FiO}_{2}$ and static $\mathrm{Crs}$ between baseline and $\mathrm{P} 2$ timepoints were compared between the COVID-19 ARDS and non-COVID ARDS groups using multivariable linear regression analysis. Comparisons between the matched samples were performed similarly (17). Because there are no definite well-known predictors for response to prone positioning, we adjusted for age, sex, body mass index, duration of mechanical ventilation before the initiation of prone positioning, sequential organ failure assessment (SOFA) score, Charlson comorbidity index (CCI), and baseline setting of mechanical ventilator (positive end-expiratory pressure [PEEP] and tidal volume) as well as baseline $\mathrm{PaO}_{2} / \mathrm{FiO}_{2}$ ratio, static $\mathrm{Crs}$, and ventilatory ratio. Ventilatory ratio was selected as a parameter to assess the efficacy of ventilation because we did not routinely monitor the expired $\mathrm{CO}_{2}$ level (18).

For patients with COVID-19 ARDS treated using prone positioning, we assessed whether the response of $\mathrm{PaO}_{2} / \mathrm{FiO}_{2}$ and static $\mathrm{Crs}$ could predict patients' probability of successful discontinuation of mechanical ventilation within 90 days using a receiver operating characteristic (ROC) analysis. In addition, the Fine and Gray competing risk regression analysis was performed to calculate the subdistribution hazard ratio (SHR) and 95\% confidence interval (CI) with adjustment for age, sex, SOFA 
score, $\mathrm{CCl}$, and baseline $\mathrm{PaO}_{2} / \mathrm{FiO}_{2}$ ratio and static $\mathrm{Crs}(19,20)$. Death occurring during mechanical ventilation was considered as the competing event. Patients who were still dependent on mechanical ventilation were censored at 90 days after the first prone positioning session. All statistical analyses were performed using STATA software (version 14.0; StataCorp LP, College Station, TX, USA).

\section{Results}

\section{Clinical characteristics of patients}

Until December 2020, 46 patients with COVID-19 ARDS were treated at our center using mechanical ventilation. Among them, 23 patients (50\%) did not start prone positioning because their oxygenation status rapidly improved after initiation of mechanical ventilation. The remaining 23 patients (50\%) were treated using prone positioning for persistent moderate-to-severe ARDS. The median interval between the diagnosis of COVID-19 and initiation of prone positioning was 9 (interquartile range [IQR] 412) days. To compare with patients with COVID-19 ARDS, 145 patients with non-COVID ARDS treated using prone positioning were reviewed and among them, two subgroups of 23 patients (1:1 matched for $\mathrm{PaO}_{2} / \mathrm{FiO}_{2}$ ratio and static $\mathrm{Crs}$, respectively) were selected.

Comparison of baseline characteristics and respiratory mechanics between these groups are described in Tables 1 and 2. The patients with non-COVID ARDS had more comorbidities and they were more severely ill with more organ dysfunctions and higher SOFA scores than the patients with COVID-19 ARDS. They also showed worse oxygenation (median $\mathrm{PaO}_{2} / \mathrm{FiO}_{2}$ ratio 96 vs. $107 \mathrm{mmHg}, P=0.037$ ) and lower static $\mathrm{Crs}$ (median 21.9 vs. $27.2 \mathrm{~mL} / \mathrm{cmH}_{2} \mathrm{O}, P=0.005$ ). All patients in both groups received ventilation with low tidal volume, but patients with non-COVID ARDS had higher ventilatory ratio (median 2.2 vs. $1.7, P<0.001$ ), requiring higher minute ventilation (median 177 vs. $140 \mathrm{~mL} / \mathrm{kg} / \mathrm{min}, P<0.001$ ). Among the patients with non-COVID ARDS, 1:1 matching was well performed, showing no between-group differences in the median values of $\mathrm{PaO}_{2} / \mathrm{FiO}_{2}$ ratio and static $\mathrm{Crs}$ in $\mathrm{PaO}_{2} / \mathrm{FiO}_{2}$-matched and compliance-matched samples, respectively.

\section{Oxygenation and static compliance responses}

The changes in $\mathrm{PaO}_{2} / \mathrm{FiO}_{2}$ ratio and static $\mathrm{Crs}$ after the first session of prone positioning are depicted in Figure 1. Baseline measurements were performed at a median of 1.3 (IQR 0.7-2.8) hours before initiation of prone positioning. Measurements for P1 and P2 timepoints were performed at a median of 9.7 (IQR 7.6-11.2) hours and 16.0 (IQR 13.5-17.8) hours after initiation of prone positioning, respectively. Most patients with COVID-19 ARDS showed improvement in both $\mathrm{PaO}_{2} / \mathrm{FiO}_{2}$ ratio and static Crs after prone positioning. The increase in $\mathrm{PaO}_{2} / \mathrm{FiO}_{2}$ ratio was the most prominent at the $\mathrm{P} 1$ timepoint and it slightly decreased when patients were moved to a supine position (Figure 1A). The static Crs showed a continuous gradual increase during the first prone positioning session (Figure 1B). A detailed comparison between patients with COVID-19 ARDS and those with non-COVID ARDS is presented in Table 3. 
When comparing baseline and $\mathrm{P} 2$ timepoints, the absolute improvement in $\mathrm{PaO}_{2} / \mathrm{FiO}_{2}$ ratio was higher in patients with COVID-19 ARDS (median 89.8 [IQR 35.3-135.2] mmHg) than in patients with nonCOVID ARDS (median 40.1 [IQR 7.0-77.5] mmHg). The difference between the two groups remained significant after adjusting for other variables when the analysis was conducted using the entire group of patients with non-COVID ARDS (adjusted difference 39.3 [95\% Cl 5.2-73.5] mmHg). However, when compared with the matched subgroups of patients with non-COVID ARDS, it was not significant (adjusted difference 4.0 [95\% $\mathrm{Cl}-62.9-71.0] \mathrm{mmHg}$ in $\mathrm{PaO}_{2} / \mathrm{FiO}_{2}$-matched samples and 58.4 [95\% $\left.\mathrm{Cl}-13.5-130.2\right]$ $\mathrm{mmHg}$ in compliance-matched samples).

The absolute change in static $\mathrm{Crs}$ between baseline and $\mathrm{P} 2$ timepoints was also higher in patients with COVID-19 ARDS (median 3.7 [IQR - 1.0-7.3] $\mathrm{mL} / \mathrm{cmH}_{2} \mathrm{O}$ ) than in patients with non-COVID ARDS (median -0.3 [IQR -4.0-1.9] mL/ $\mathrm{cmH}_{2} \mathrm{O}$ ). However, similar to the case of $\mathrm{PaO}_{2} / \mathrm{FiO}_{2}$ ratio, after adjusting for other variables, this difference in static Crs was significant only when the analysis was conducted using the entire group of patients with non-COVID ARDS (adjusted difference 3.4 [95\% Cl 1.1-5.6] $\mathrm{mL} / \mathrm{cmH}_{2} \mathrm{O}$ ). The significance was lost in the analysis of matched samples (adjusted difference 0.3 [95\% $\mathrm{Cl}-3.3-3.8] \mathrm{mL} / \mathrm{cmH}_{2} \mathrm{O}$ in $\mathrm{PaO}_{2} / \mathrm{FiO}_{2}$-matched samples and 2.2 [95\% $\mathrm{Cl}-2$.4-6.7] $\mathrm{mL} / \mathrm{cmH}_{2} \mathrm{O}$ in compliance-matched samples).

Association between clinical outcomes

In patients with COVID-19 ARDS, successful discontinuation of mechanical ventilation was achieved in 16 of 23 patients (69.6\%) within 90 days after the first session of prone positioning. We evaluated whether the changes in $\mathrm{PaO}_{2} / \mathrm{FiO}_{2}$ ratio and static $\mathrm{Crs}$ after the first prone positioning session were associated with successful discontinuation of mechanical ventilation. In ROC analysis, the areas under the curve were 0.893 (0.754-1.000) for the change in $\mathrm{PaO}_{2} / \mathrm{FiO}_{2}$ ratio and 0.866 (0.714-1.000) for the change in static $\mathrm{Crs}$ (Figure 2). In competing risk regression analysis, the extent of improvement in $\mathrm{PaO}_{2} / \mathrm{FiO}_{2}$ ratio (SHR $1.19,95 \% \mathrm{Cl} 1.08-1.30$ per $10 \mathrm{mmHg}$ increase) and static Crs (SHR $1.57,95 \% \mathrm{Cl}$ 1.29-1.91 per $1 \mathrm{~mL} / \mathrm{cmH}_{2} \mathrm{O}$ increase) after the first prone positioning session were both associated with successful discontinuation of mechanical ventilation (Table 4). Among other variables, female sex, lower SOFA score, and higher baseline static Crs were associated with higher probability of successful discontinuation of mechanical ventilation.

\section{Discussion}

In this study, we compared the physiological response of prone positioning between patients with COVID-19 ARDS and non-COVID ARDS, focusing on changes in oxygenation and static Crs. Most patients with COVID-19 ARDS showed improvement in $\mathrm{PaO}_{2} / \mathrm{FiO}_{2}$ ratio and static Crs after the first session of prone positioning. The extent of improvement in these parameters appeared to be higher in patients with COVID-19 ARDS when compared crudely with the entire group of patients with non-COVID ARDS.

However, when 1:1 matched samples $\left(\mathrm{PaO}_{2} / \mathrm{FiO}_{2}\right.$-matched and compliance-matched) were analyzed, the 
physiological response to prone positioning was not different between patients with COVID-19 ARDS and those with non-COVID ARDS.

Whether patients with COVID-19 ARDS have a clinically different phenotype compared with those with typical non-COVID ARDS continues to be a controversial issue $(5,21)$. One of the issues related to this controversy is regarding static Crs. Since the COVID-19 pandemic started, some patients with COVID19 ARDS have been reported to have preserved static Crs despite impaired oxygenation, which is referred to as "type L (low elastance) phenotype" compared with "type H (high elastance) phenotype" $(21,22)$. A multicenter study in Italy reported that patients with COVID-19 ARDS had higher median static Crs than those with non-COVID ARDS ( 41 vs. $32 \mathrm{~mL} / \mathrm{cmH}_{2} \mathrm{O}$ ), although there was a substantial overlap between the two groups (11). However, in several other studies, patients with COVID-19 ARDS presented with static Crs of approximately $30-35 \mathrm{~mL} / \mathrm{cmH}_{2} \mathrm{O}$, which is similar to that in previous reports of typical non-COVID $\operatorname{ARDS}(6,10,23-26)$.

In our study, patients in both groups showed substantially reduced static Crs (median 27.2 and $21.9 \mathrm{~mL} / \mathrm{cmH}_{2} \mathrm{O}$ in COVID-19 and non-COVID group, respectively). Especially, patients with non-COVID ARDS in this study had extremely poor static Crs considering that a recent secondary analysis of the LUNG SAFE study, which included a large multinational cohort of patients, reported the median static Crs of $30 \mathrm{~mL} / \mathrm{cmH}_{2} \mathrm{O}$ (27). This may be due to the selection bias that occurs in single-center studies. In fact, we could not identify any patient in either group (COVID-19 or non-COVID) who can be classified as having type $L$ phenotype (static $\mathrm{Crs} \geq 50 \mathrm{~mL} / \mathrm{cmH}_{2} \mathrm{O}$ ). Therefore, our findings may not be applicable to patients with type L phenotype.

Almost every patient with COVID-19 ARDS in this study showed improvement in $\mathrm{PaO}_{2} / \mathrm{FiO}_{2}$ ratio after prone positioning. Such improvement was rapid and most noticeable after 10 hours of prone positioning. This finding is consistent with that of another single-center study of intubated patients with COVID-19 treated using prone positioning, which reported that $\mathrm{PaO}_{2} / \mathrm{FiO}_{2}$ ratio improved within 2 hours after initiation of prone positioning (28). In a prospective study of prone positioning in nonintubated patients, improvement in oxygenation was observed even 10 minutes after initiation of prone positioning (29). In contrast, a previous study on non-COVID ARDS showed that the oxygenation status was not always improved immediately after initiation of prone positioning (30). In other studies, including the PROSEVA trial, $\mathrm{PaO}_{2} / \mathrm{FiO}_{2}$ ratio was higher at the end of the prone positioning session than at 1 hour after initiation of prone positioning, which is similar to our findings for patients with non-COVID ARDS (7, 31). Based on these findings, it can be suggested that the speed of the oxygenation response after prone positioning may differ between patients with COVID-19 ARDS and those with non-COVID ARDS. Because $\mathrm{PaO}_{2} / \mathrm{FiO}_{2}$ ratio cannot be monitored on real-time basis, monitoring oxygenation based on $\mathrm{SpO}_{2} / \mathrm{FiO}_{2}$ ratio might provide more information on this issue.

The change in static Crs after prone positioning has not been studied as much as the change in oxygenation. In one study, static Crs was improved with prone positioning when it was accompanied only 
with application of high PEEP, but not with low PEEP (32). Crs is determined by compliance of the chest wall and lung. Because chest wall compliance usually decreases during prone positioning, the overall change in Crs after prone positioning depends on how much the compliance of the lung improves, which may be related to lung recruitability (8). In our study, the extent of improvement in static $\mathrm{Crs}$ after prone positioning appeared to be higher in patients with COVID-19 ARDS than in patients with non-COVID ARDS in a crude analysis. However, the difference was not significant when the analysis was performed using the matched samples. In addition to static $\mathrm{Crs}$, it may be useful to monitor the lung recruitability while implementing prone positioning (33-36).

The major finding of our study was that oxygenation and Crs responses after prone positioning were not different between patients with COVID-19 ARDS and those with non-COVID ARDS after careful matching and adjusting for baseline between-group differences. Because non-COVID ARDS comprises lung injuries from very heterogeneous causes, it is not easy to make a proper comparison between the two groups. Furthermore, although COVID-19 ARDS occurs by infection caused by a common single pathogen, results of several studies indicated that respiratory mechanics of patients with COVID-19 ARDS show a substantial interindividual variability, highlighting the importance of individualization in ventilator management (37). As in our study, it may be because of this interindividual variability that other studies also failed to identify significant differences between COVID-19 ARDS and non-COVID ARDS $(38,39)$. However, our finding suggests prone positioning in patients with COVID-19 ARDS is at least as effective in improving respiratory physiology as in patients with typical non-COVID ARDS.

We have recently reported that the extent of improvement in oxygenation after the first session of prone positioning could be predictive of clinical outcome for patients with non-COVID ARDS (9). In this study, we confirmed this finding in patients with COVID-19 ARDS. In addition, we found that the improvement in static Crs after prone positioning was also associated with clinical outcome. Therefore, if the physiological effect of prone positioning is not substantial at the end of first session, intensivists may have to consider another therapeutic options.

Our study has several limitations. First, our study was conducted at a single center and the number of patients studied was limited, although we enrolled every consecutive patient treated using prone positioning until December 2020. Second, despite our efforts to adjust for between-group differences including 1:1 matched analysis, we cannot exclude the possibility that uncontrolled individual factors affected our study findings. Third, we could not evaluate the effect of prone positioning in patients with preserved static Crs (type L phenotype), because there were no such patients in our cohort.

\section{Conclusions}

In conclusion, in patients with COVID-19 ARDS, prone positioning was as effective in improving oxygenation and static $\mathrm{Crs}$ as in patients with non-COVID ARDS. Although interindividual variability in respiratory mechanics indicates the need for more individualized approaches in ventilator management, our study findings suggest that prone positioning should be actively considered for patients with 
moderate-to-severe COVID-19 ARDS. In addition, the physiological response to the first session of prone positioning should be monitored to predict the future clinical outcome.

\section{Abbreviations}

Acute respiratory distress syndrome, ARDS

Charlson comorbidity index, $\mathrm{CCl}$

Confidence interval, $\mathrm{Cl}$

Coronavirus disease 2019, COVID-19

Fraction of inspired oxygen, $\mathrm{FiO}_{2}$

Interquartile range, IQR

Partial pressure of arterial oxygen, $\mathrm{PaO}_{2}$

Positive end-expiratory pressure, PEEP

Receiver operating characteristics, ROC

Respiratory system compliance, Crs

Sequential organ failure assessment, SOFA

Subdistribution hazard ratio, SHR

\section{Declarations}

Ethics approval and consent to participate: This study was approved by the institutional review board and informed consent was waived because this study was considered as posing minimal risk to the study participants because of its retrospective study design.

Consent for publication: Not applicable.

Availability of data and materials: The datasets used and/or analyzed during the current study are available from the corresponding author on reasonable request.

Competing interests: The authors declare that they have no competing interests.

Funding: There was no funding for this study.

Authors' contributions: SML is the study lead and guarantor for this paper. JP, HYL, JL, and SML contributed to conception and design of the study. JP and HYL contributed to acquisition, analysis, and 
interpretation of data. JP and HYL performed the main statistical analysis, and JL and SML critically appraised those results. JP wrote the first draft of this paper, and HYL, JL, and SML revised it critically for important intellectual content. JP, HYL, JL, and SML had access to final version of this paper and approved it to be published. JP, HYL, JL, and SML reached agreement to be accountable for all aspects of the work in ensuring that questions related to the accuracy or integrity of any part of the work are appropriately investigated and resolved.

Acknowledgements: Not applicable.

\section{References}

1. Guan W-j, Ni Z-y, Hu Y, Liang W-h, Ou C-q, He J-x, et al. Clinical Characteristics of Coronavirus Disease 2019 in China. N Engl J Med. 2020;382(18):1708-20.

2. Hu Y, Sun J, Dai Z, Deng H, Li X, Huang Q, et al. Prevalence and severity of corona virus disease 2019 (COVID-19): A systematic review and meta-analysis. J Clin Virol. 2020;127:104371.

3. Tan E, Song J, Deane AM, Plummer MP. Global Impact of Coronavirus Disease 2019 Infection Requiring Admission to the ICU: A Systematic Review and Meta-analysis. Chest. 2021;159(2):524-36.

4. Wiersinga WJ, Rhodes A, Cheng AC, Peacock SJ, Prescott HC. Pathophysiology, Transmission, Diagnosis, and Treatment of Coronavirus Disease 2019 (COVID-19): A Review. JAMA. 2020;324(8):782-93.

5. Gattinoni L, Coppola S, Cressoni M, Busana M, Rossi S, Chiumello D. COVID-19 Does Not Lead to a "Typical" Acute Respiratory Distress Syndrome. Am J Respir Crit Care Med. 2020;201(10):1299-300.

6. Ferrando C, Suarez-Sipmann F, Mellado-Artigas R, Hernandez M, Gea A, Arruti E, et al. Clinical features, ventilatory management, and outcome of ARDS caused by COVID-19 are similar to other causes of ARDS. Intensive Care Med. 2020;46(12):2200-11.

7. Guerin C, Reignier J, Richard JC, Beuret P, Gacouin A, Boulain T, et al. Prone positioning in severe acute respiratory distress syndrome. N Engl J Med. 2013;368(23):2159-68.

8. Guerin C, Albert RK, Beitler J, Gattinoni L, Jaber S, Marini JJ, et al. Prone position in ARDS patients: why, when, how and for whom. Intensive Care Med. 2020;46(12):2385-96.

9. Lee HY, Cho J, Kwak N, Choi SM, Lee J, Park YS, et al. Improved Oxygenation After Prone Positioning May Be a Predictor of Survival in Patients With Acute Respiratory Distress Syndrome. Crit Care Med. 2020;48(12):1729-36.

10. Botta M, Tsonas AM, Pillay J, Boers LS, Algera AG, Bos LDJ, et al. Ventilation management and clinical outcomes in invasively ventilated patients with COVID-19 (PRoVENT-COVID): a national, multicentre, observational cohort study. Lancet Respir Med. 2021;9(2):139-48.

11. Grasselli G, Tonetti T, Protti A, Langer T, Girardis M, Bellani G, et al. Pathophysiology of COVID-19associated acute respiratory distress syndrome: a multicentre prospective observational study. Lancet Respir Med. 2020;8(12):1201-8. 
12. Beigel JH, Tomashek KM, Dodd LE, Mehta AK, Zingman BS, Kalil AC, et al. Remdesivir for the Treatment of Covid-19 - Final Report. N Engl J Med. 2020;383(19):1813-26.

13. Group RC, Horby P, Lim WS, Emberson JR, Mafham M, Bell JL, et al. Dexamethasone in Hospitalized Patients with Covid-19. N Engl J Med. 2021;384(8):693-704.

14. Roca O, Caralt B, Messika J, Samper M, Sztrymf B, Hernandez G, et al. An Index Combining Respiratory Rate and Oxygenation to Predict Outcome of Nasal High-Flow Therapy. Am J Respir Crit Care Med. 2019;199(11):1368-76.

15. Papazian L, Forel JM, Gacouin A, Penot-Ragon C, Perrin G, Loundou A, et al. Neuromuscular blockers in early acute respiratory distress syndrome. N Engl J Med. 2010;363(12):1107-16.

16. Rosenbaum PR. Optimal Matching for Observational Studies. J Am Stat Assoc. 1989;84(408):102432.

17. Pearce N. Analysis of matched case-control studies. BMJ. 2016;352:i969.

18. Sinha P, Calfee CS, Beitler JR, Soni N, Ho K, Matthay MA, et al. Physiologic Analysis and Clinical Performance of the Ventilatory Ratio in Acute Respiratory Distress Syndrome. Am J Respir Crit Care Med. 2019;199(3):333-41.

19. Fine JP, Gray RJ. A Proportional Hazards Model for the Subdistribution of a Competing Risk. J Am Stat Assoc. 1999;94(446):496-509.

20. Yehya N, Harhay MO, Curley MAQ, Schoenfeld DA, Reeder RW. Reappraisal of Ventilator-Free Days in Critical Care Research. Am J Respir Crit Care Med. 2019;200(7):828-36.

21. Gattinoni L, Chiumello D, Caironi P, Busana M, Romitti F, Brazzi L, et al. COVID-19 pneumonia: different respiratory treatments for different phenotypes? Intensive Care Med. 2020;46(6):1099-102.

22. Gattinoni L, Chiumello D, Rossi S. COVID-19 pneumonia: ARDS or not? Crit Care. 2020;24(1):154.

23. Schenck EJ, Hoffman K, Goyal P, Choi J, Torres L, Rajwani K, et al. Respiratory Mechanics and Gas Exchange in COVID-19-associated Respiratory Failure. Ann Am Thorac Soc. 2020;17(9):1158-61.

24. Vandenbunder B, Ehrmann S, Piagnerelli M, Sauneuf B, Serck N, Soumagne T, et al. Static compliance of the respiratory system in COVID-19 related ARDS: an international multicenter study. Crit Care. 2021;25(1):52.

25. Cummings MJ, Baldwin MR, Abrams D, Jacobson SD, Meyer BJ, Balough EM, et al. Epidemiology, clinical course, and outcomes of critically ill adults with COVID-19 in New York City: a prospective cohort study. Lancet. 2020;395(10239):1763-70.

26. COVID-ICU Group on behalf of the REVA Network and the COVID-ICU Investigators. Clinical characteristics and day-90 outcomes of 4244 critically ill adults with COVID-19: a prospective cohort study. Intensive Care Med. 2021;47(1):60-73.

27. Panwar R, Madotto F, Laffey JG, van Haren FMP. Compliance Phenotypes in Early Acute Respiratory Distress Syndrome before the COVID-19 Pandemic. Am J Respir Crit Care Med. 2020;202(9):1244-52.

28. Weiss TT, Cerda F, Scott JB, Kaur R, Sungurlu S, Mirza SH, et al. Prone positioning for patients intubated for severe acute respiratory distress syndrome (ARDS) secondary to COVID-19: a 
retrospective observational cohort study. Br J Anaesth. 2021;126(1):48-55.

29. Coppo A, Bellani G, Winterton D, Di Pierro M, Soria A, Faverio P, et al. Feasibility and physiological effects of prone positioning in non-intubated patients with acute respiratory failure due to COVID-19 (PRON-COVID): a prospective cohort study. Lancet Respir Med. 2020;8(8):765-74.

30. Albert RK, Keniston A, Baboi L, Ayzac L, Guérin C. Prone Position-induced Improvement in Gas Exchange Does Not Predict Improved Survival in the Acute Respiratory Distress Syndrome. Am J Respir Crit Care Med. 2014;189(4):494-6.

31. Haddam M, Zieleskiewicz L, Perbet S, Baldovini A, Guervilly C, Arbelot C, et al. Lung ultrasonography for assessment of oxygenation response to prone position ventilation in ARDS. Intensive Care Med. 2016;42(10):1546-56.

32. Cornejo RA, Diaz JC, Tobar EA, Bruhn AR, Ramos CA, Gonzalez RA, et al. Effects of prone positioning on lung protection in patients with acute respiratory distress syndrome. Am J Respir Crit Care Med. 2013;188(4):440-8.

33. Haudebourg AF, Perier F, Tuffet S, de Prost N, Razazi K, Mekontso Dessap A, et al. Respiratory Mechanics of COVID-19- versus Non-COVID-19-associated Acute Respiratory Distress Syndrome. Am J Respir Crit Care Med. 2020;202(2):287-90.

34. Chen L, Del Sorbo L, Grieco DL, Junhasavasdikul D, Rittayamai N, Soliman I, et al. Potential for Lung Recruitment Estimated by the Recruitment-to-Inflation Ratio in Acute Respiratory Distress Syndrome. A Clinical Trial. Am J Respir Crit Care Med. 2020;201(2):178-87.

35. Pan C, Chen L, Lu C, Zhang W, Xia JA, Sklar MC, et al. Lung Recruitability in COVID-19-associated Acute Respiratory Distress Syndrome: A Single-Center Observational Study. Am J Respir Crit Care Med. 2020;201(10):1294-7.

36. Mauri T, Spinelli E, Scotti E, Colussi G, Basile MC, Crotti S, et al. Potential for Lung Recruitment and Ventilation-Perfusion Mismatch in Patients With the Acute Respiratory Distress Syndrome From Coronavirus Disease 2019. Crit Care Med. 2020;48(8):1129-34.

37. Fan E, Beitler JR, Brochard L, Calfee CS, Ferguson ND, Slutsky AS, et al. COVID-19-associated acute respiratory distress syndrome: is a different approach to management warranted? Lancet Respir Med. 2020;8(8):816-21.

38. Bain W, Yang H, Shah FA, Suber T, Drohan C, Al-Yousif N, et al. COVID-19 versus Non-COVID ARDS: Comparison of Demographics, Physiologic Parameters, Inflammatory Biomarkers and Clinical Outcomes. Ann Am Thorac Soc. 2021 [In press].

39. Grieco DL, Bongiovanni F, Chen L, Menga LS, Cutuli SL, Pintaudi G, et al. Respiratory physiology of COVID-19-induced respiratory failure compared to ARDS of other etiologies. Crit Care. 2020;24(1):529.

\section{Tables}

Table 1. Patient characteristics 


\begin{tabular}{|c|c|c|c|c|c|c|c|}
\hline \multirow[t]{3}{*}{ Variables } & \multirow{2}{*}{$\begin{array}{l}\text { COVID- } \\
19 \\
\text { ARDS } \\
\\
\text { Entire } \\
\text { group }\end{array}$} & \multicolumn{6}{|c|}{ Non-COVID ARDS } \\
\hline & & $\begin{array}{l}\text { Entire } \\
\text { group }\end{array}$ & $\begin{array}{l}P \\
\text { value }^{\mathrm{a}}\end{array}$ & $\begin{array}{l}\mathrm{PaO}_{2} / \mathrm{FiO}_{2}- \\
\text { matched }\end{array}$ & $\begin{array}{l}P \\
\text { value }^{\mathrm{a}}\end{array}$ & $\begin{array}{l}\text { Compliance- } \\
\text { matched }\end{array}$ & $\begin{array}{l}P \\
\text { value }^{\mathrm{a}}\end{array}$ \\
\hline & $N=23$ & $N=145$ & & $N=23$ & & $N=23$ & \\
\hline Age, years & $\begin{array}{l}70(63- \\
74)\end{array}$ & $\begin{array}{l}67(59- \\
74)\end{array}$ & 0.222 & $\begin{array}{l}75(70- \\
79)\end{array}$ & 0.092 & $66(60-74)$ & 0.159 \\
\hline Male sex & $\begin{array}{l}15 \\
(65.2 \%)\end{array}$ & $\begin{array}{l}97 \\
(66.9 \%)\end{array}$ & 0.874 & 17 (73.9\%) & 0.522 & $16(69.6 \%)$ & 0.753 \\
\hline Height, cm & $165 \pm 9$ & $163 \pm 8$ & 0.374 & $163 \pm 10$ & 0.614 & $164 \pm 8$ & 0.791 \\
\hline Body weight, kg & $\begin{array}{l}70(58- \\
79)\end{array}$ & $\begin{array}{l}61(53- \\
70)\end{array}$ & 0.018 & $\begin{array}{l}57(51- \\
69)\end{array}$ & 0.015 & $64(55-69)$ & 0.132 \\
\hline $\begin{array}{l}\text { Body mass } \\
\text { index, } \mathrm{kg} / \mathrm{m}^{2}\end{array}$ & $\begin{array}{l}25.6 \\
(22.9- \\
27.4)\end{array}$ & $\begin{array}{l}22.9 \\
(20.8- \\
26.0)\end{array}$ & 0.024 & $\begin{array}{l}22.5 \\
(19.3- \\
24.7)\end{array}$ & 0.009 & $\begin{array}{l}22.7(20.5- \\
27.2)\end{array}$ & 0.121 \\
\hline $\begin{array}{l}\text { Interval between } \\
\text { intubation } \\
\text { and the first } \\
\text { prone } \\
\text { positioning } \\
\text { session, days }\end{array}$ & $1(0-2)$ & $2(1-5)$ & 0.009 & $1(0-3)$ & 0.116 & $2(1-4)$ & 0.047 \\
\hline $\begin{array}{l}\text { Total number of } \\
\text { sessions of } \\
\text { prone } \\
\text { positioning }\end{array}$ & $4(3-9)$ & $2(1-4)$ & $<0.001$ & $2(1-4)$ & 0.008 & $2(1-4)$ & 0.011 \\
\hline $\begin{array}{l}\text { Mean duration } \\
\text { of prone } \\
\text { positioning per } \\
\text { session, hours }\end{array}$ & $\begin{array}{l}18(17- \\
19)\end{array}$ & $\begin{array}{l}18(16- \\
19)\end{array}$ & 0.653 & $\begin{array}{l}17(16- \\
18)\end{array}$ & 0.180 & $17(16-20)$ & 0.231 \\
\hline $\begin{array}{l}\text { Charlson } \\
\text { comorbidity } \\
\text { index }\end{array}$ & $4(3-4)$ & $5(3-8)$ & 0.012 & $5(4-6)$ & 0.011 & $5(4-7)$ & 0.032 \\
\hline APACHE II score & $\begin{array}{l}20(12- \\
25)\end{array}$ & $\begin{array}{l}29(25- \\
33)\end{array}$ & $<0.001$ & $\begin{array}{l}30(26- \\
35)\end{array}$ & $<0.001$ & $29(25-37)$ & $<0.001$ \\
\hline SAPS II score & $\begin{array}{l}42(31- \\
61)\end{array}$ & $\begin{array}{l}65(55- \\
71)\end{array}$ & $<0.001$ & $\begin{array}{l}66(62- \\
78)\end{array}$ & $<0.001$ & $65(58-78)$ & $<0.001$ \\
\hline SOFA score & $\begin{array}{l}8(5- \\
11)\end{array}$ & $\begin{array}{l}12(9- \\
14)\end{array}$ & $<0.001$ & $12(9-14)$ & 0.002 & $13(11-15)$ & $<0.001$ \\
\hline
\end{tabular}


APACHE, Acute Physiology and Chronic Health Evaluation; ARDS, acute respiratory distress syndrome; SAPS, Simplified Acute Physiology Score; SOFA, Sequential Organ Failure Assessment

a $P$ values are for comparison between patients with COVID-19 ARDS and patients with non-COVID ARDS.

Table 2. Baseline respiratory mechanics and clinical outcomes 


\begin{tabular}{|c|c|c|c|c|c|c|c|}
\hline Variables & COVID- & Non-COVI & ARDS & & & & \\
\hline & $\begin{array}{l}\text { Entire } \\
\text { group }\end{array}$ & $\begin{array}{l}\text { Entire } \\
\text { group }\end{array}$ & $\begin{array}{l}P \\
\text { value }^{\mathrm{a}}\end{array}$ & $\begin{array}{l}\mathrm{PaO}_{2} / \mathrm{FiO}_{2}^{-} \\
\text {matched }\end{array}$ & $\begin{array}{l}P \\
\text { value }^{\mathrm{a}}\end{array}$ & $\begin{array}{l}\text { Compliance- } \\
\text { matched }\end{array}$ & $\begin{array}{l}P \\
\text { value }^{\mathrm{a}}\end{array}$ \\
\hline & $N=23$ & $N=145$ & & $N=23$ & & $N=23$ & \\
\hline $\begin{array}{l}\text { Arterial blood } \\
\text { gas analysis }\end{array}$ & & & & & & & \\
\hline $\mathrm{pH}$ & $\begin{array}{l}7.37 \\
(7.34-\end{array}$ & $\begin{array}{l}7.34 \\
(7.28-\end{array}$ & & $\begin{array}{l}7.36 \\
(7.26-\end{array}$ & & $\begin{array}{l}7.34(7.28- \\
7.41)\end{array}$ & \\
\hline $\mathrm{PaCO}_{2}, \mathrm{mmHa}$ & 7.39) & 7.40) & 0.139 & 7.40) & 0.071 & $46(37-54)$ & 0.860 \\
\hline$x_{0}, 100$ & $\begin{array}{l}44(40- \\
49)\end{array}$ & $\begin{array}{l}49(40- \\
55)\end{array}$ & 0.467 & $48(45-$ & 0.391 & $69(55-78)$ & 0.097 \\
\hline $\mathrm{PaO}_{2}, \mathrm{mmHg}$ & & & 0.161 & & 0.191 & $09(50-10)$ & 0.240 \\
\hline $\mathrm{HCO}_{3}, \mathrm{mEq} / \mathrm{L}$ & $\begin{array}{l}75(66- \\
80)\end{array}$ & $\begin{array}{l}71(62- \\
85)\end{array}$ & & $\begin{array}{l}79(65- \\
93)\end{array}$ & & $\begin{array}{l}23.3(18.6- \\
28.6)\end{array}$ & \\
\hline & $\begin{array}{l}24.9 \\
(24.1- \\
28.4)\end{array}$ & $\begin{array}{l}24.2 \\
(21.5- \\
27.3)\end{array}$ & & $\begin{array}{l}23.3(21- \\
28.6)\end{array}$ & & & \\
\hline Ventilator $\mathrm{FiO}_{2}$ & $\begin{array}{l}0.7 \\
(0.6- \\
0.8)\end{array}$ & $\begin{array}{l}0.8 \\
(0.65- \\
1.0)\end{array}$ & 0.047 & $\begin{array}{l}0.75(0.6- \\
0.9)\end{array}$ & 0.537 & $\begin{array}{l}0.75(0.7- \\
1.0)\end{array}$ & 0.221 \\
\hline $\begin{array}{l}\mathrm{PaO}_{2} / \mathrm{FiO}_{2} \text { ratio, } \\
\mathrm{mmHg}\end{array}$ & $\begin{array}{l}107 \\
(92- \\
132)\end{array}$ & $\begin{array}{l}96(74- \\
120)\end{array}$ & 0.037 & $\begin{array}{l}107(92- \\
131)\end{array}$ & 1.000 & $\begin{array}{l}90(72- \\
104)\end{array}$ & 0.007 \\
\hline PEEP, $\mathrm{cmH}_{2} \mathrm{O}$ & $\begin{array}{l}12(9- \\
13)\end{array}$ & $\begin{array}{l}\text { 10 (8- } \\
11)\end{array}$ & 0.016 & $10(7-10)$ & 0.063 & $10(8-11)$ & 0.135 \\
\hline $\begin{array}{l}\text { Driving } \\
\text { pressure, } \\
\mathrm{cmH}_{2} \mathrm{O}\end{array}$ & $\begin{array}{l}13(12- \\
16)\end{array}$ & $\begin{array}{l}18(15- \\
21)\end{array}$ & $<0.001$ & $\begin{array}{l}18(15- \\
22)\end{array}$ & 0.001 & $15(13-18)$ & 0.096 \\
\hline $\begin{array}{l}\text { Respiratory rate, } \\
\text { breaths/min }\end{array}$ & $\begin{array}{l}21(19- \\
27)\end{array}$ & $\begin{array}{l}27(24- \\
30)\end{array}$ & 0.002 & $\begin{array}{l}26(25- \\
30)\end{array}$ & 0.012 & $24(21-30)$ & 0.116 \\
\hline $\begin{array}{l}\text { Tidal volume } \\
\text { per PBW, mL/kg }\end{array}$ & $\begin{array}{l}6.3 \\
(5.6- \\
7.0)\end{array}$ & $\begin{array}{l}6.6(6.0- \\
7.3)\end{array}$ & 0.126 & $\begin{array}{l}6.4(5.9- \\
7.2)\end{array}$ & 0.734 & $\begin{array}{l}6.5(5.9- \\
9.0)\end{array}$ & 0.177 \\
\hline $\begin{array}{l}\text { Minute } \\
\text { ventilation } \\
\text { per PBW, } \\
\mathrm{mL} / \mathrm{kg} / \mathrm{min}\end{array}$ & $\begin{array}{l}140 \\
(123- \\
171)\end{array}$ & $\begin{array}{l}177 \\
(145- \\
200)\end{array}$ & $<0.001$ & $\begin{array}{l}167(133- \\
193)\end{array}$ & 0.044 & $\begin{array}{l}173(141- \\
194)\end{array}$ & 0.003 \\
\hline $\begin{array}{l}\text { Static } \\
\text { respiratory } \\
\text { system }\end{array}$ & $\begin{array}{l}27.2 \\
(21.9- \\
32.7)\end{array}$ & $\begin{array}{l}21.9 \\
(18.2- \\
26.5)\end{array}$ & 0.005 & $\begin{array}{l}20.0 \\
(15.6- \\
27.2)\end{array}$ & 0.008 & $\begin{array}{l}27.2(21.9- \\
32.7)\end{array}$ & 0.983 \\
\hline
\end{tabular}




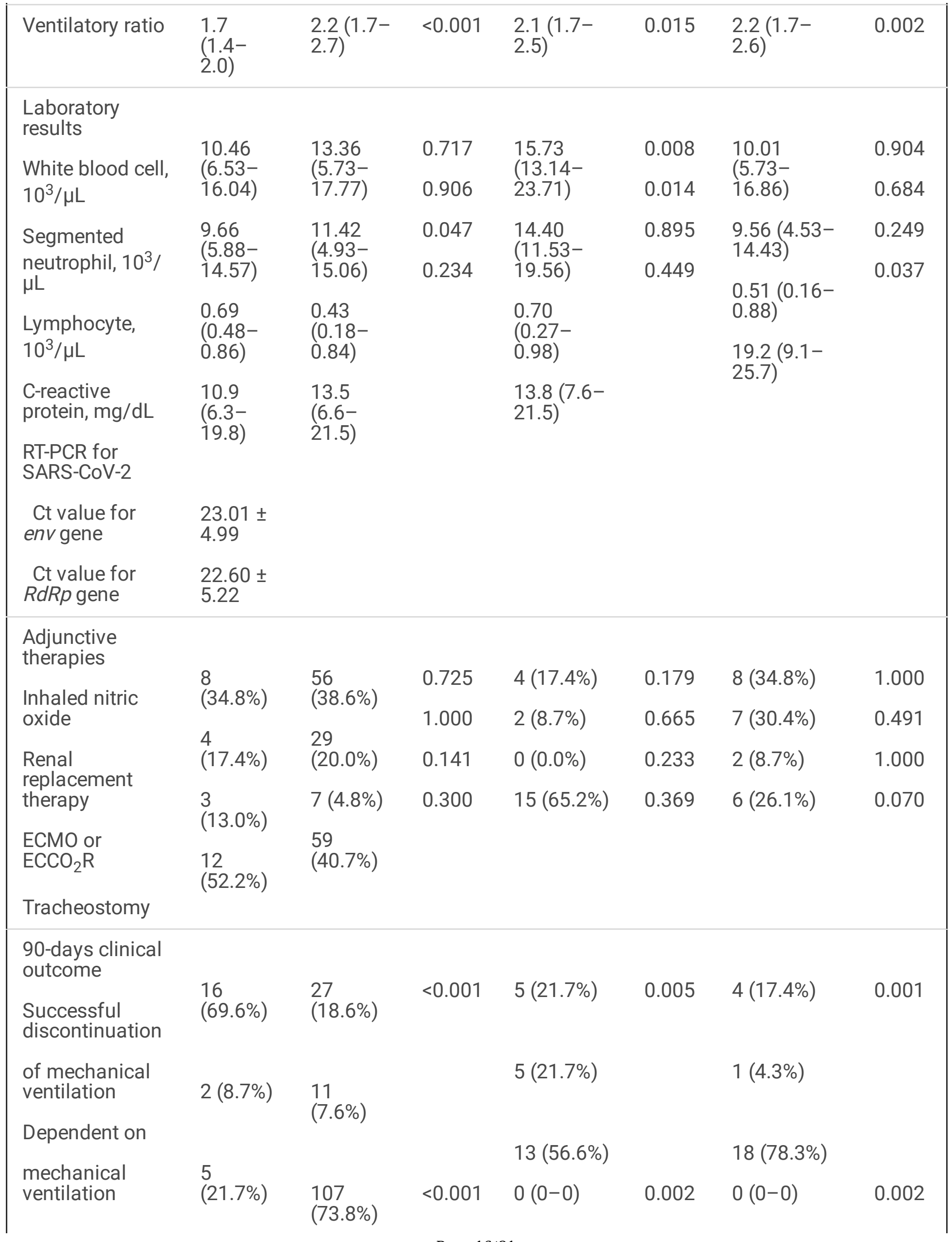


Death $\quad 45(0-\quad 0(0-0)$

Ventilator free

82)

days

ARDS, acute respiratory distress syndrome; Ct value, cycle threshold value; $\mathrm{ECCO}_{2} \mathrm{R}$, extracorporeal carbon dioxide removal; ECMO, extracorporeal membrane oxygenation; $\mathrm{FiO}_{2}$, fraction of inspired oxygen; $\mathrm{PaCO}_{2}$, partial pressure of carbon dioxide; $\mathrm{PaO}_{2}$, partial pressure of oxygen; PBW, predicted body weight; PEEP, positive end expiratory pressure; RT-PCR, reverse transcription polymerase chain reaction

a $P$ values are for comparison between patients with COVID-19 ARDS and patients with non-COVID ARDS.

Table 3. $\mathrm{PaO}_{2} / \mathrm{FiO}_{2}$ ratio and static respiratory system compliance responses after the first prone positioning session 


\begin{tabular}{|c|c|c|c|c|c|c|}
\hline & $\begin{array}{l}\text { Entire } \\
\text { group }\end{array}$ & & $\begin{array}{l}\mathrm{PaO}_{2} / \mathrm{FiO}_{2}- \\
\text { matched }\end{array}$ & & $\begin{array}{l}\text { Compliance- } \\
\text { matched }\end{array}$ & \\
\hline & $N=168$ & $\begin{array}{l}P \\
\text { value }\end{array}$ & $N=46$ & $\begin{array}{l}P \\
\text { value }\end{array}$ & $N=46$ & $\begin{array}{l}P \\
\text { value }\end{array}$ \\
\hline \multicolumn{7}{|l|}{$\mathrm{PaO}_{2} / \mathrm{FiO}_{2}$ ratio } \\
\hline $\begin{array}{l}\text { Change at the end of the } \\
\text { first }\end{array}$ & & 0.003 & & 0.091 & & $<0.001$ \\
\hline $\begin{array}{l}\text { prone positioning session, } \\
\mathrm{mmHg}\end{array}$ & $\begin{array}{l}89.8 \\
(35.3- \\
135.2)\end{array}$ & & $\begin{array}{l}89.8(35.3- \\
135.2)\end{array}$ & & $\begin{array}{l}89.8(35.3- \\
135.2)\end{array}$ & \\
\hline $\begin{array}{l}\text { COVID-19 ARDS, median } \\
\text { (IQR) }\end{array}$ & $\begin{array}{l}40.1(7.0- \\
77.5)\end{array}$ & & $\begin{array}{l}48.7(5.0- \\
87.0)\end{array}$ & & $\begin{array}{l}21.1(0.0- \\
43.8)\end{array}$ & \\
\hline \multicolumn{7}{|l|}{$\begin{array}{l}\text { Non-COVID ARDS, } \\
\text { median (IQR) }\end{array}$} \\
\hline \multicolumn{7}{|l|}{$\begin{array}{l}\text { Regression coefficient } \\
\text { (COVID vs. non-COVID) }\end{array}$} \\
\hline Unadjusted $(95 \% \mathrm{Cl})$ & $\begin{array}{l}46.7 \\
(17.8- \\
75.6)\end{array}$ & $\begin{array}{l}0.002 \\
0.024\end{array}$ & $\begin{array}{l}32.5 \\
(-14.7- \\
79.8)\end{array}$ & $\begin{array}{l}0.172 \\
0.903\end{array}$ & $\begin{array}{l}69.7(31.2- \\
108.2)\end{array}$ & \multirow[t]{2}{*}{$\begin{array}{l}0.001 \\
0.108\end{array}$} \\
\hline Adjusted $(95 \% \mathrm{Cl})^{\mathrm{a}}$ & $\begin{array}{l}39.3(5.2- \\
73.5)\end{array}$ & & $\begin{array}{l}4.0(-62.9- \\
71.0)\end{array}$ & & $\begin{array}{l}58.4(-13.5- \\
130.2)\end{array}$ & \\
\hline \multicolumn{7}{|l|}{$\begin{array}{l}\text { Static respiratory system } \\
\text { compliance }\end{array}$} \\
\hline $\begin{array}{l}\text { Change at the end of the } \\
\text { first }\end{array}$ & & \multirow[t]{4}{*}{$<0.001$} & & 0.044 & & \multirow[t]{4}{*}{$<0.001$} \\
\hline prone positioning session, & $\begin{array}{l}3.7(-1.0- \\
7.3)\end{array}$ & & $\begin{array}{l}3.7(-1.0- \\
7.3)\end{array}$ & & $\begin{array}{l}3.7(-1.0- \\
7.3)\end{array}$ & \\
\hline $\begin{array}{l}\text { COVID-19 ARDS, median } \\
(\text { IQR) }\end{array}$ & \multirow[t]{2}{*}{$\begin{array}{l}-0.3(-4.0- \\
1.9)\end{array}$} & & \multirow[t]{2}{*}{$\begin{array}{l}0.4(-1.2- \\
2.3)\end{array}$} & & \multirow[t]{2}{*}{$\begin{array}{l}-2.3(-7.2- \\
0.0)\end{array}$} & \\
\hline $\begin{array}{l}\text { Non-COVID ARDS, } \\
\text { median (IQR) }\end{array}$ & & & & & & \\
\hline $\begin{array}{l}\text { Regression coefficient } \\
\text { (COVID vs. non-COVID) }\end{array}$ & & & & & & \multirow{3}{*}{$\begin{array}{l}<0.001 \\
0.340\end{array}$} \\
\hline Unadjusted $(95 \% \mathrm{Cl})$ & $\begin{array}{l}4.2(2.3- \\
6.2)\end{array}$ & \multirow{2}{*}{$\begin{array}{l}<0.001 \\
0.003\end{array}$} & $\begin{array}{l}2.7(0.0- \\
5.5)\end{array}$ & \multirow{2}{*}{$\begin{array}{l}0.047 \\
0.883\end{array}$} & $\begin{array}{l}6.6(3.8- \\
9.3)\end{array}$ & \\
\hline Adjusted $(95 \% \mathrm{Cl})^{\mathrm{a}}$ & $\begin{array}{l}3.4(1.1- \\
5.6)\end{array}$ & & $\begin{array}{l}0.3(-3.3- \\
3.8)\end{array}$ & & $\begin{array}{l}2.2(-2.4- \\
6.7)\end{array}$ & \\
\hline
\end{tabular}

$\mathrm{Cl}$, confidence interval; $\mathrm{FiO}_{2}$, fraction of inspired oxygen; IQR, interquartile range; $\mathrm{PaO}_{2}$, partial pressure of oxygen 
a For multivariable linear regression, the following variables were adjusted: age, sex, body mass index, duration of mechanical ventilation before initiation of prone positioning, sequential organ failure assessment (SOFA) score, Charlson comorbidity index (CCl), baseline setting of mechanical ventilator (positive end-expiratory pressure and tidal volume), and baseline respiratory mechanics before initiation of prone positioning $\left(\mathrm{PaO}_{2} / \mathrm{FiO}_{2}\right.$, static compliance, and ventilatory ratio).

Table 4. Predictors of successful discontinuation of mechanical ventilation for patients with COVID-19 ARDS

\begin{tabular}{|c|c|c|}
\hline Predictors $(\mathrm{N}=23)$ & $\begin{array}{l}\text { Subdistribution hazard } \\
\text { ratio }^{a}\end{array}$ & $\begin{array}{l}P \\
\text { value }\end{array}$ \\
\hline Age (per 1 year) & $1.18(0.99-1.40)$ & 0.063 \\
\hline Female sex (vs. Male sex) & $13.92(1.17-165.15)$ & 0.037 \\
\hline SOFA score (per 1 point) & $0.68(0.49-0.95)$ & 0.022 \\
\hline Charlson comorbidity index (per 1 point) & $0.48(0.17-1.39)$ & 0.176 \\
\hline Baseline $\mathrm{PaO}_{2} / \mathrm{FiO}_{2}$ ratio (per $10 \mathrm{mmHg}$ ) & $0.73(0.53-1.00)$ & 0.054 \\
\hline $\begin{array}{l}\text { Baseline static respiratory system compliance (per } 1 \\
\mathrm{~mL} / \mathrm{cmH}_{2} \mathrm{O} \text { ) }\end{array}$ & $1.40(1.10-1.79)$ & 0.006 \\
\hline $\begin{array}{l}\text { Increase in } \mathrm{PaO}_{2} / \mathrm{FiO}_{2} \text { ratio after } \\
\text { the first prone positioning session (per } 10 \mathrm{mmHg} \text { ) }\end{array}$ & $1.19(1.08-1.30)$ & $<0.001$ \\
\hline $\begin{array}{l}\text { Increase in static respiratory system compliance after } \\
\text { the first prone positioning session (per } 1 \mathrm{~mL} / \mathrm{cmH}_{2} \mathrm{O} \text { ) }\end{array}$ & $1.57(1.29-1.91)$ & $<0.001$ \\
\hline
\end{tabular}

$\mathrm{FiO}_{2}$, fraction of inspired oxygen; $\mathrm{PaO}_{2}$, partial pressure of oxygen; SOFA, Sequential Organ Failure Assessment

a Subdistribution hazard ratios are described with their $95 \%$ confidence intervals.

\section{Figures}




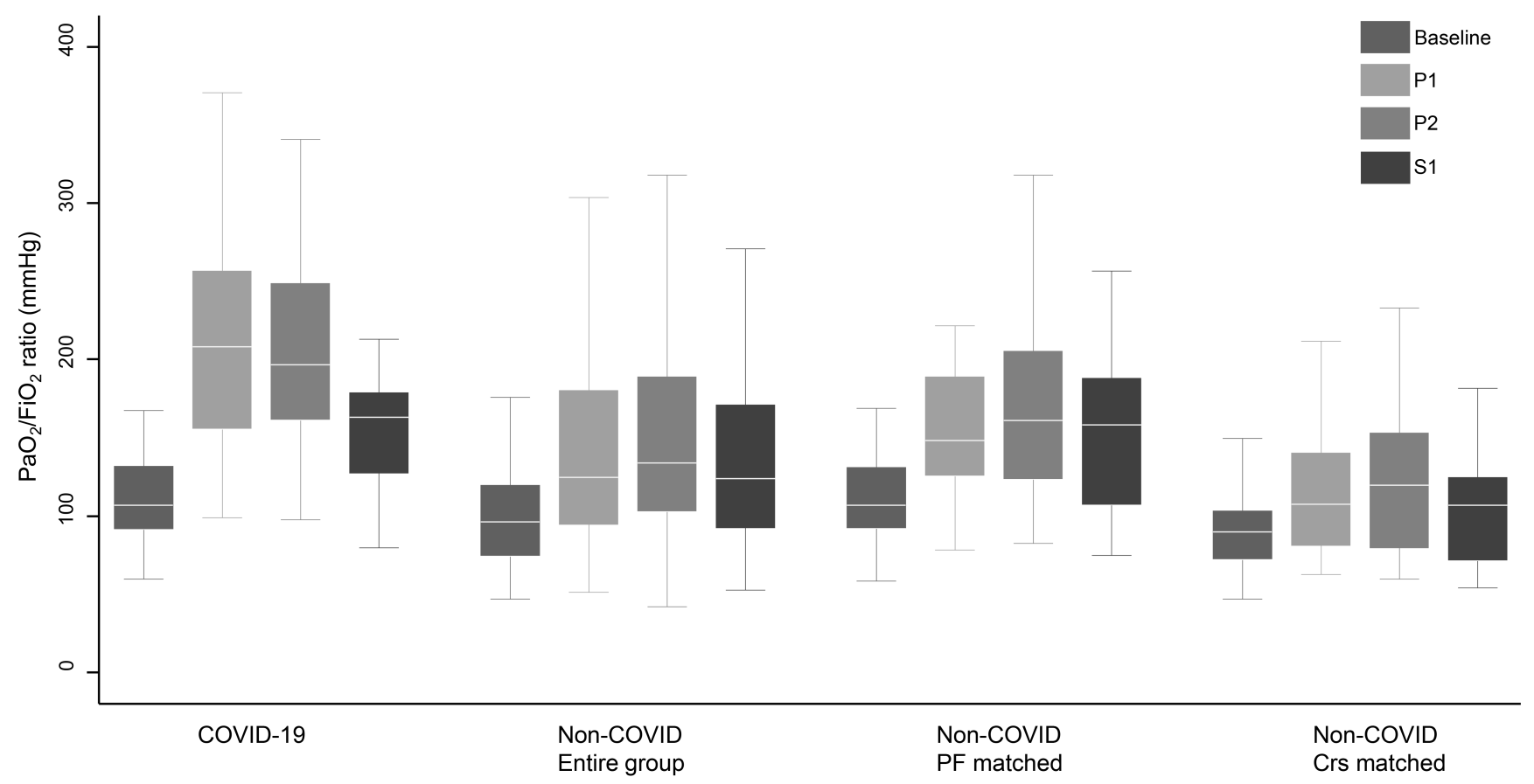

B

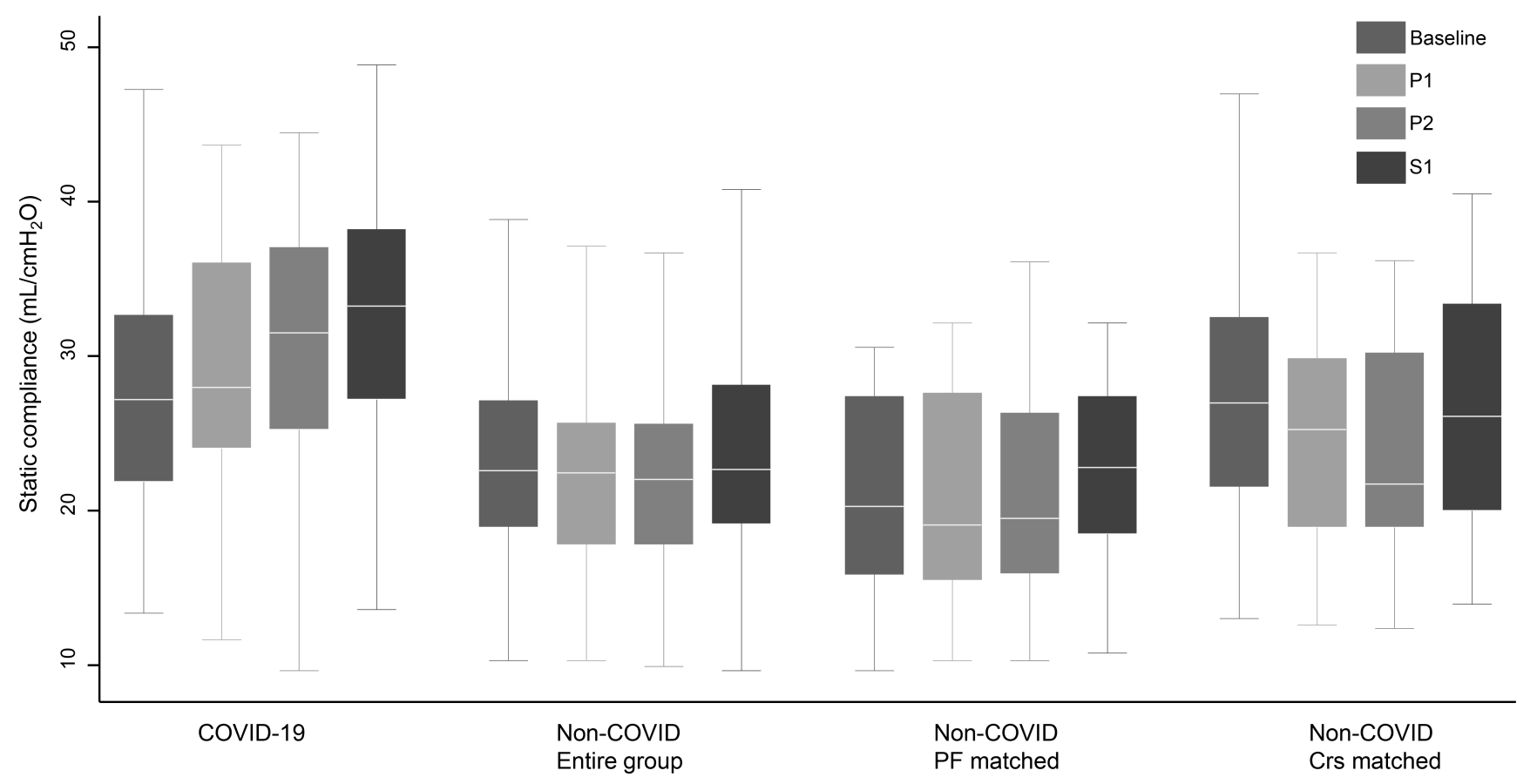

Figure 1

Changes in $\mathrm{PaO} 2 / \mathrm{FiO} 2$ ratio and static respiratory system compliance after the first session of prone positioning. A) PaO2/FiO2 ratio; B) Static respiratory system compliance 
A

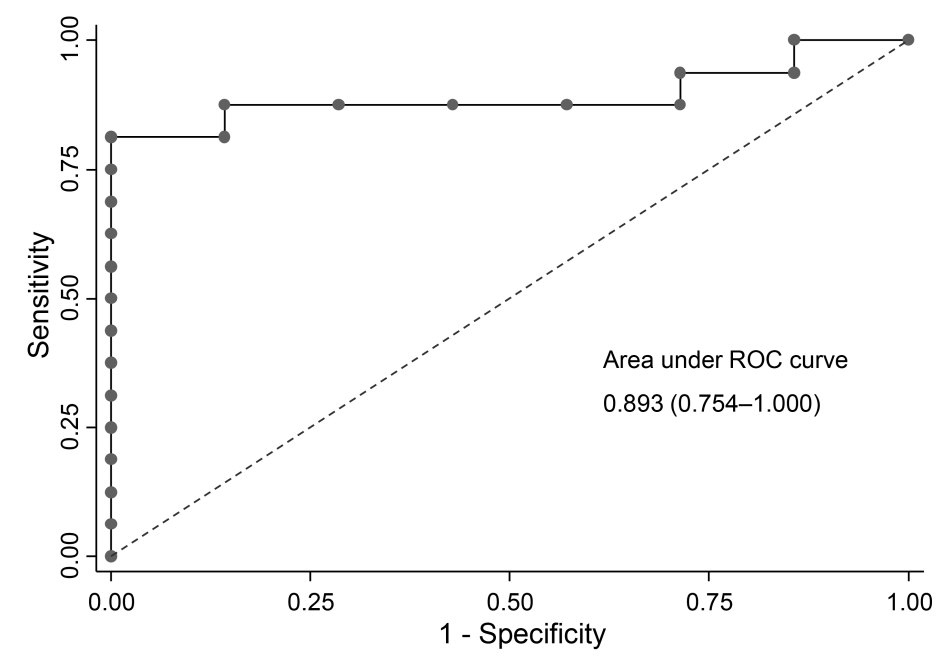

B

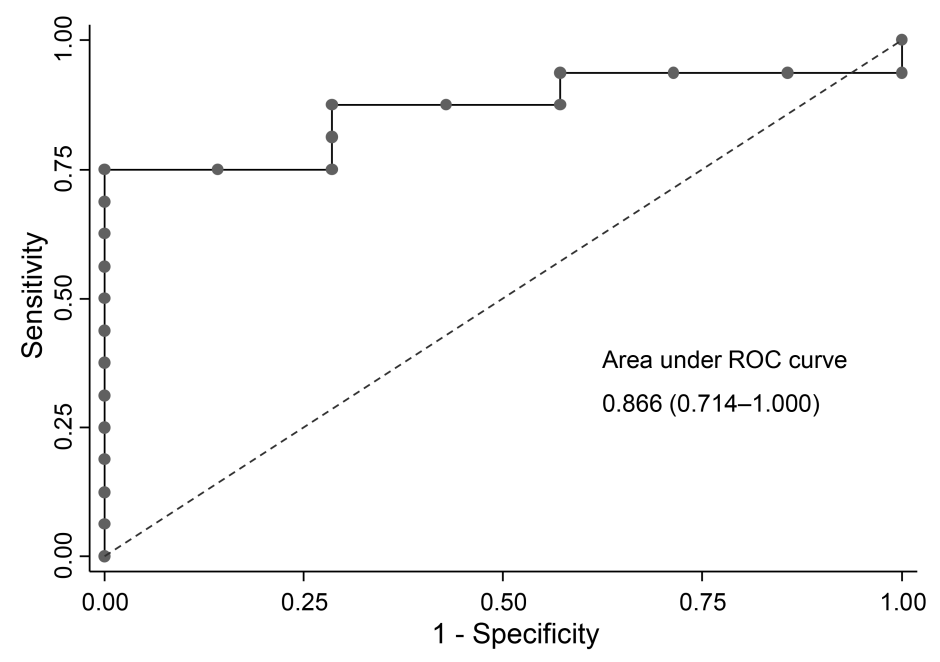

\section{Figure 2}

Receiver operating characteristic curve for changes in $\mathrm{PaO2} / \mathrm{FiO} 2$ ratio and static respiratory system compliance in predicting the successful discontinuation of mechanical ventilation. A) PaO2/FiO2 ratio; B) Static respiratory system compliance 